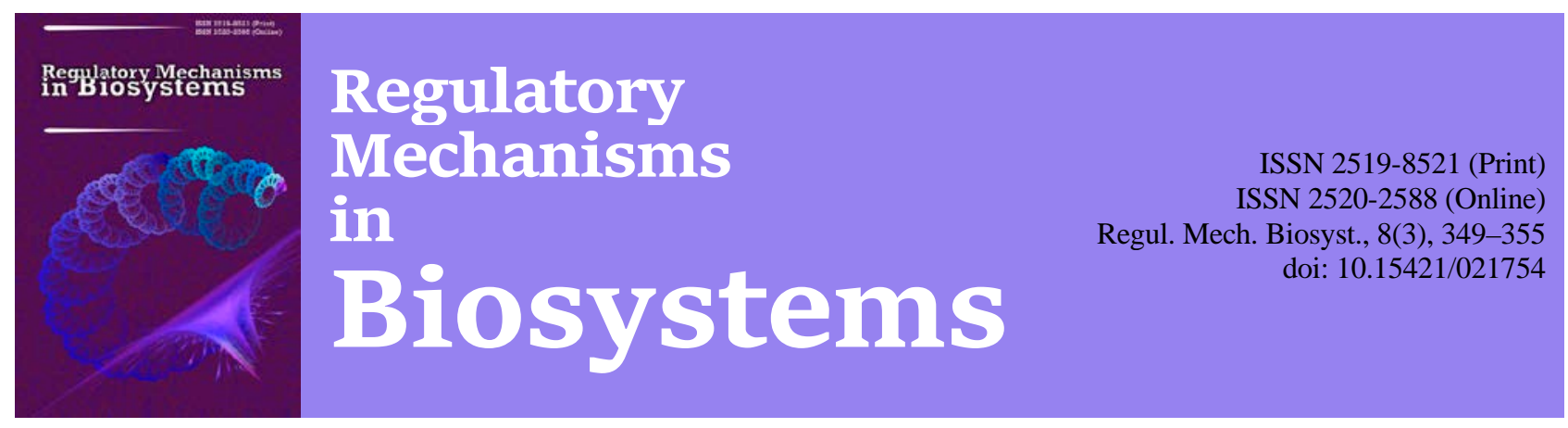

\title{
Biomorphology and rhythm of seasonal development of the relic species Lobelia dortmanna in oligotrophic lakes of Tver region
}

\author{
A. G. Lapirov*, E. A. Belyakov*,**, O. A. Lebedeva* \\ *I. D. Papanin Institute for Biology of Inland Waters RAS, Borok, Russia \\ **Cherepovets State University, Cherepovets, Russia
}

Article info

Received 18.06.2017

Received in revised form 14.07.2017

Accepted 20.07.2017

I. D. Papanin Institute for Biology of Inland Waters RAS, Borok,

Nekouz District, Yaroslavl

Region, 152742, Russia.

Tel.: +48-547-240-42.

E-mail: lapir@ibiw.yaroslavl.ru

Cherepovets State University,

Lunacharsky Ave., 5 ,

Cherepovets, 162600, Russia
Lapirov, A. G., Belyakov, E. A., \& Lebedeva, O. A. (2017). Biomorphology and rhythm of seasonal development of the relic species Lobelia dortmanna in oligotrophic lakes of Tver region. Regulatory Mechanisms in Biosystems, 8(3), 349-355. doi: 10.15421/021754

This article covers the morphology of the vegetative and generative sphere of a rare relic species, Lobelia dortmanna L. (Lobelioideae). This is the first time that using the modular approach a study has analysed the shoot system of this species and described the structures of all three categories: elementary (EM), universal (UM) and basic (OM). This paper describes the life form and analyses the rhythm of seasonal development of the species in the lakes of Tver oblast, and provides data on the seed productivity. As a life form, L. dortmanna is a herbaceous polycarpic, unclearly polycentric shallow-rooted plant with a fibrous root system and non-specialized morphological disintegration. The sympodially growing shoot-system of the plant is formed by two types of different-aged anisotropic replacement shoots: dicyclic vegetative-generative semirosette and annual vegetative rosette shoots. The indicator of actual seed productivity equals on average up to $1621 \pm 451$ seeds per single vegetative-generative shoot. The module structure of L. dortmanna is presented by 10 variants of elementary modules. The main modules are formed on the basis of a monocarpic dicyclic anisotropic monopodial shoot with the following morpho-functional zones distinguished: 1) the lower zone of inhibition; 2) the recovery zone; 3) the upper zone of inhibition 4) the latent generative zone; 5) the main inflorescence. The functional role of the first three morpho-functional zones of a monocarpic shoot is performed by a minimum number of variants of elementary modules. In the rhythm of seasonal development, the authors distinguished 7 consecutive stages: 1) the period of relative rest; 2) vegetative phase; 3) the phase of budding; 4) flowering; 5) fruiting; 6) secondary activities. By the character of rhythm of seasonal development, L. dortmanna belongs to the group of evergreen plants with a long growing season and middle-late summer flowering.

Keywords: morphology; vegetative and generative sphere; universal and basic modules; rhythm of development

\section{Биоморфология и ритм сезонного развития реликтового вида Lobelia dortmanna в олиготрофных озерах Тверской области}

\author{
А. Г. Лапиров*, Е. А. Беляков*, **, О. А. Лебедева* \\ *Институт биологии внутренних вод имени И. Д. Папанина РАН, Борок, Россия \\ **Череповеикий государственный университет, Череповеи, Россия
}

Рассмотрены морфология вегетативной и генеративной сферы редкого реликтового вида - лобелии Дортманна, Lobelia dortmanna L. (Lobelioideae). Впервые с помощью модульного подхода проанализирована побеговая система этого вида, определены структуры всех трех категорий модулей: элементарного (ЭМ), универсального (УМ) и основного (ОМ). Описана жизненная форма и рассмотрен ритм сезонного развития этого вида на озерах Тверской области, приведены данные по семенной продуктивности. По жизненной форме L. dortmanna является травянистым поликарпиком, неявнополицентрическим короткокорневищным малолетником вегетативного происхождения с кистекорневой системой и ранней неспециализированной морфологической дезинтеграцией. Нарастающая симподиально побеговая система растения образована двумя типами разновозрастных анизотропных побегов замещения: дициклическими вегетативно-генеративными полурозеточными и однолетними вегетативными розеточными. Величина фактической семенной продуктивности L. dortmanna в озерах Тверской области, в среднем, достигает $1621 \pm 451$ семя на один вегетативно-генеративный побег. Модульная структура L. dortmanna представлена 10 вариантами элементарных модулей. Основные модули формируются на основе монокарпического дициклического анизотропного моноподиального побега, в рамках которого выделен ряд морфофункциональных зон: 1) нижняя зона торможения; 2) зона возобновления; 3) верхняя зона торможения 4) скрытогенеративная зона; 5) главное соцветие. При этом функциональная роль трех первых морфофункциональных зон монокарпического побега обеспечивается малым числом вариантов элементарных модулей. При описании ритма сезонного развития 
авторами выделено несколько последовательных этапов: 1) период относительного покоя; 2) вегетативная фаза; 3) фаза бутонизации; 4) цветения; 5) плодоношения; 6) вторичной деятельности. По характеру ритма сезонного развития L. dortmanna относится к группе длительновегетирующих летнезимнезеленых растений со средне- и позднелетним периодом цветения.

Ключевые слова: морфология вегетативной и генеративной сферы; универсальный и основной модули; ритм развития

\section{Введение}

Lobelia dortmanna L., лобелия Дортманна - индикатор олиготрофных озерных экосистем, редкий и исчезающий вид, доминирующий в растительности бедных питательными веществами озер Европы и Северной Америки (Szmeja, 1987; SandJensen et al., 2005; Møller and Sand-Jensen, 2011). В России это растение спорадически встречается в северных областях Европейской части; в Средней России отмечено лишь в некоторых озерах Тверской области (Gubanov et al., 2004), где считалось единственным представителем атлантических видов (Nevskiy, 1956). Этот вид относится к группе так называемых «изоэтидов» - специфических погруженных растений с низкими трофическими требованиями (Lamentowicz and Milecka, 2004; Sand-Jensen et al., 2005; Pulido et al., 2012). Морфологические характеристики этих растений сопряжены с ростом в бедных углеродом олиготрофных озерах и характеризуются розеткой коротких листьев (<10 см), плотной, хорошо развитой корневой системой, обширными воздушными внутренними лакунами в листьях и корнях и хлоропластами вблизи лакун (Raven et al., 1988 - цит. по Pedersen and Sand-Jensen, 1992).

Несмотря на то, что лобелия Дортманна давно представляет интерес для ботаников (Szmeja, 1987), ее морфологические особенности и ритм сезонного развития изучены недостаточно полно. Имеющиеся морфологические работы, в основном зарубежных исследователей, относятся к середине XIX века, началу и 40-50-м годам XX века (Buchenau, 1866; Tswett, 1907; Aberg, 1943 - все цит. по: Szmeja, 1987; Sylven, 1903; Ydrac, 1905 - все, цит. по: Woodhead, 1951; Armand, 1912; Glück, 1924; Philipson, 1948). Краткие сведения по этому вопросу приводятся в немногочисленных отечественных работах (Philippov et al., 2016; Markov, 2017). Работ по ритму сезонного развития лобелии также крайне мало. Подробные сведения по ритму сезонного развития в одном из олиготрофных озер на севере Польши (Lake Wielkie Oczko), включающему 8 фенологических фаз, представлены польским исследователем Szmeja (1987). До настоящего времени это единственная известная нам работа подобного плана. Остальные, в лучшем случае, описывают лишь особенности цветения и плодоношения (Woodhead, 1951; Farmer and Spence, 1987).

В связи с вышеизложенным, цель данной работы - охарактеризовать биоморфологию и ритм сезонного развития L. dortmanna в олиготрофных озерах Тверской области.

\section{Материал и методы исследований}

В основу работы положены материалы оригинальных исследований L. dortmanna, проведенных в 2014-2016 гг. на водоемах Тверской области: Вышневолоцкий р-н - озера Бель-

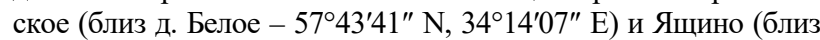

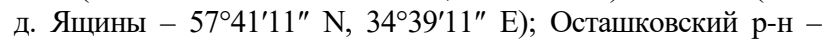
озера Сиг (окрестности деревень Куряево - 5701'28,4" N, $33^{\circ} 06^{\prime} 36^{\prime \prime}$ Е, Буковичи - 57 $03^{\prime} 15^{\prime \prime} \mathrm{N}, 33^{\circ} 11^{\prime} 02^{\prime \prime}$ Е и Краклово -

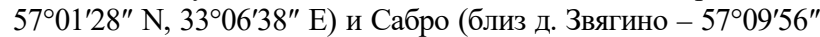
N, 32 54'19" Е и пос. Дубье - 5708'31" N, 3253'06" Е).

На исследованных озерах $L$. dortmanna растет на глубинах $0,2-1,2$ м и более на песчаном или песчаном с наилком грунтах в виде отдельных экземпляров, небольших групп растений или обширных пятен (шириной более 50 и длиной более 200 м, оз. Бельское) с высоким проективным покрытием (до 100\%). Группировки данного вида сосредоточены, в основном, в тростниковых зарослях, либо на защищенных (реже не защищенных) от волнового действия открытых пространствах. Для исследования биоморфологии лобелии Дортманна использова- ли преимущественно живой, фиксированный, а также гербарный материал фондов IBIW, MHA и MW. Всего проанализировано 90-100 побегов, находящихся в разных онтогенетических состояниях. В качестве основных подходов при проведении исследования выбраны классические методы: сравнительно-морфологический и ритмологический, применяемые при изучении водных и прибрежно-водных растений (Savinykh and Cheryomushkina, 2015).

Для выявления сезонных морфологических изменений раз в месяц на протяжении всего вегетационного сезона 2014-2016 гг. проводили натурные исследования и сборы в двух озерах морено-аккумулятивного происхождения - Бельское и Сиг (Тверская обл.). Собранные образцы очищали от грунта, укладывали в полиэтиленовые пакеты и доставляли в лабораторию, где проводили биометрический анализ. В вегетативной сфере отмечали длину и число междоузлий побегов, порядок их ветвления, емкости терминальных и боковых почек; определяли число листьев, их длину и ширину, подсчитывали число корней и измеряли их максимальную длину. При исследовании генеративной сферы у растений измеряли длину цветоноса и его метамеров, определяли фактическую семенную продуктивность (ФСП), включающую общее число семян на побеге (Vaynagiy, 1974). Учет числа генеративных побегов и количества семян на них в зависимости от глубины произрастания растений проводили с помощью рамки площадью $0,25 \mathrm{~m}^{2}$. Повторность для каждой из глубин 3-5-кратная.

Жизненная форма L. dortmanna описана в соответствии с алгоритмом, показанным в работе Savinykh and Cheryomushkina (2015), феноритмотип - согласно классификации фенологических типов растений (Borisova, 1972). При характеристике растительных группировок с участием L. dortmanna авторы отмечали тип водного объекта, экологические особенности местообитания (характер грунта, глубину воды), составляли список таксонов, входящих в состав биоценоза. В тексте работы и в таблицах данные представлены в виде $\mathrm{x} \pm \mathrm{SD}$.

\section{Результаты}

\section{Морфология вегетативной сферы}

Симподиальная побеговая система взрослой генеративной особи лобелии Дортманна образована розеточными участками нескольких порядков ветвления (рис 1a, б), которые постепенно погружаются в грунт благодаря наличию придаточных корней. Она представлена двумя типами разновозрастных анизотропных побегов: дициклическими вегетативно-генеративными полурозеточными и однолетними вегетативными розеточными.

Розеточные побеги конические длиной $1,8 \pm 0,9$ и диаметром $0,4 \pm 0,1$ см. На всем протяжении они несут однотипные листья: сидячие линейные цельнокрайние с тупым кончиком, $\mathrm{S}$-образно-изогнутые, длиной до 4,5 $\pm 0,6$ см и шириной - 0,30,4 см, сплюснутые до 0,15-0,20 см, темно-зеленого цвета, блестящие, зимующие. Листья хрупкие, с двумя полостями внутри. Листорасположение спиральное в четыре ряда. Число листьев на побегах варьирует в зависимости от онтогенетического состояния растения. Например, на розеточном участке генеративного побега формируется в среднем $21,5 \pm 3,5$ (в отдельных случаях до 30) листьев, в то время как у вегетативных побегов - до 28,4 $\pm 6,1$. Кроме типичных, описанных выше, листьев у этого растения имеются листья верховой формации брактеи. Последние цельные, плоские, со шпателевидной в очертании листовой пластинкой (длиной до 0,25 и шириной до 0,18 см) и городчатым краем.

В пазухах большинства листьев боковые почки не образуются. Формирование латеральных почек (в пазухах одного - 
трех последних (самых верхних) листьев розеточного участка побега) у генеративных особей происходит в период завершения закладки терминального цветоноса, либо на начальных этапах его развития. Эти почки трогаются в рост без периода покоя, образуя побеги следующего порядка ветвления (рис $1 a, 6$ ). К осени, с отмиранием терминального соцветия, розеточный участок вегетативно-генеративного побега оставляет за собой функции запасания питательных веществ. В течение следующего вегетационного сезона побеги, начавшие свое развитие в прошлом году, повторяют жизненный цикл материнского побега. Материнский участок розеточного побега $n$-го порядка постепенно отмирает к началу - концу третьего года жизни.
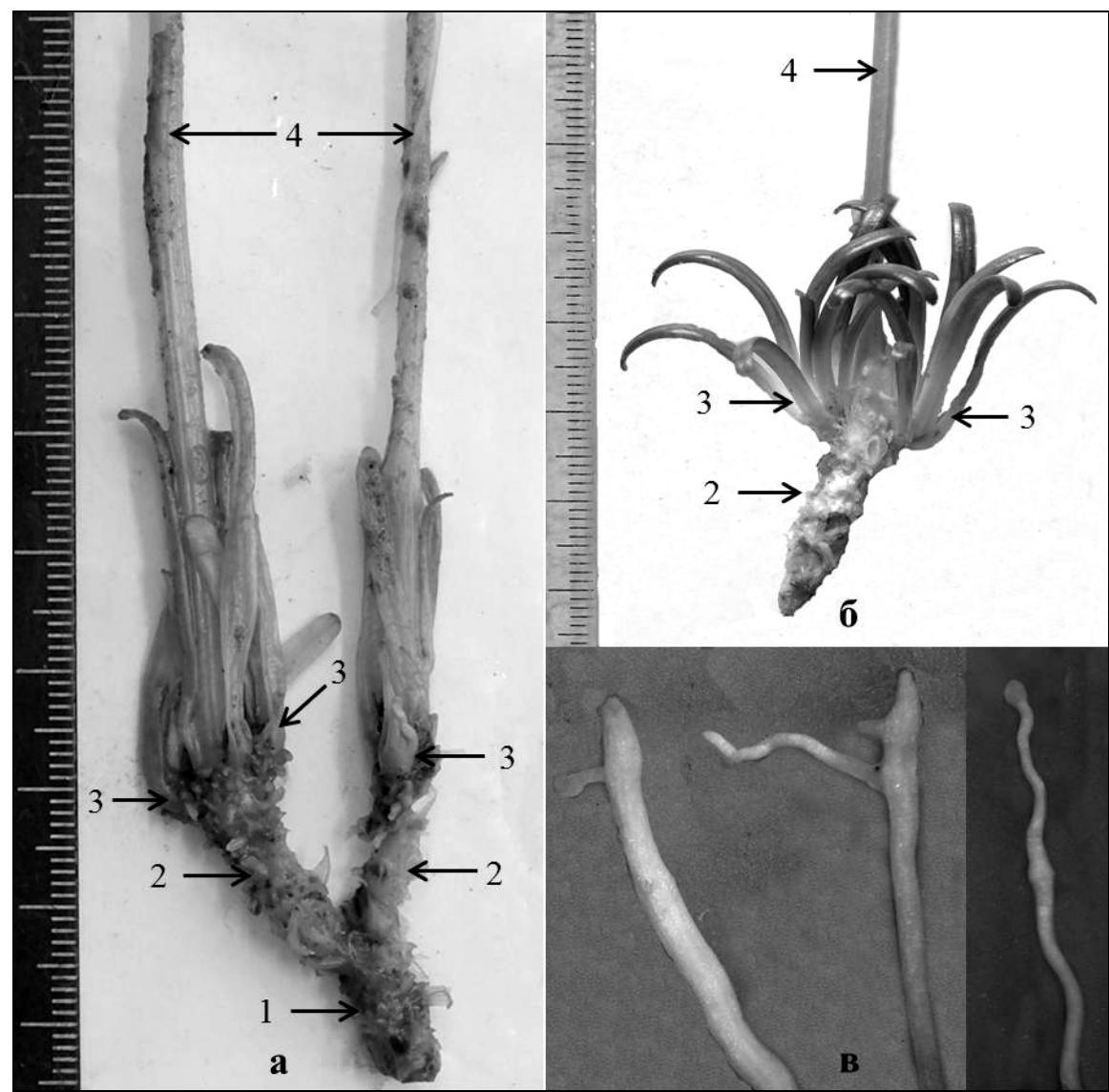

Pис. 1. L. dortmanna: $a, \sigma$ - структура побеговой системы; 8 - утолщения на корнях: 1 - розеточный участок побега $n$-го порядка (материнский) с отмершими листьями; 2 - розеточный участок вегетативно-генеративного побега $n+1$-го порядка ветвления (листья удалены); 3 - вегетативный розеточный участок побега $n+2$-го порядка ветвления (нынешнего года) с открытой верхушечной почкой и листьями; 4 - соцветие, реализованное в нынешнем году

Корневая система у L. dortmanna кистевидная, представлена многочисленными (до $65,7 \pm 33,4$ у вегетативных и $112,6 \pm$ 33,2 (иногда до 150-200) у вегетативно-генеративных) стеблеродными придаточными корнями, обычно неветвящимися, реже ветвящимися до $n+1$-го порядка. Живые корни белого цвета, 8,6 $\pm 2,0$ см длиной, по мере отмирания они обесцвечиваются. Интересно наличие на концах некоторых корней специфических утолщений (рис. 16). Активное развитие придаточных корней в базальной части розеточного побега наблюдается в течение всего вегетационного сезона, в осенне-зимний период их развитие замедляется.

\section{Морфология генеративной сферы}

Соцветие $L$. dortmanna представлено простой брактеозной кистью. Средняя длина цветоносной оси достигает 59,2 $\pm 11,0$ см, диаметр - 0,2-0,3 см. В отдельных случаях цветоносная ось может достигать 117 см (Glück, 1924). Длина метамеров оси изменяется по одновершинной кривой. На цветоносной оси (снизу вверх) располагаются сначала листья срединной формации (нередко их нижняя часть прирастает к цветоносной оси), затем братеи. При этом в нижней части соцветия (в пазухе первого - второго листа срединной формации) пазушные структуры (вегетативные почки) имеются либо отсутствуют. Выше по цветоносной оси, в пазухах третьего - четвертого (реже еще и второго) срединных листьев, а также идущих за ними двух нижних брактей, обнаружены зачаточные соцветия, которые, как правило, в рост не трогаются. Еще выше располагается участок цветоносной оси, на котором из пазух брактей выходят расположенные на цветоножках (длиной от 0,5 до 1,0 см) одиночные поникающие цветки.

Цветки обоеполые зигоморфные пятичленные с двойным околоцветником, самоопыляющиеся, венчик голубой либо бледно-фиолетовый. У лобелии нередко можно наблюдать наличие клейстогамных цветков (в нижней части соцветия, которая может быть погружена в воду). Последние выглядят также как обычные цветки и могут формировать плоды с хорошо развитыми семенами. Аналогичное явление наблюдал и Glück (1924) в природных и культуральных условиях.

Плоды L. dortmanna представляют собой овальные тонкоребристые коробочки с двумя створками (Gubanov et al., 2004; Lebedeva and Belyakov, 2016). Формирование и созревание семян происходит не одновременно. Первыми созревают плоды, располагающиеся (нередко под водой) в нижней части соцветия. Коробочка имеет эллиптическую форму $(1,5 \pm 1,1$ см длиной и 0,4 см диаметром), резко сужающуюся в верхней части в столбик (до 0,4 см длиной). Содержимое плода разделено на два гнезда. Число созревших коробочек с семенами на один монокарпический побег достигает 3-6 штук. Часть цветков не успевает сформировать плоды.

Семена правильной эллиптической формы (длиной 0,4-0,6 и шириной $0,3-0,4$ мм) с блестящей темно- либо светло-коричневой семенной оболочкой (Lebedeva and Belyakov, 2016) с характерной бугристой скульптурой; с прямым зародышем и разви- 
тым эндоспермом. Характерной особенностью семян является полное отсутствие у них плавучести, что препятствует их распространению даже на небольшие расстояния в водоеме. У растений с исследуемых озер среднее число семян, приходящихся на коробочку, достигает $319 \pm 55$, а среднее число семян в одном гнезде $-160 \pm 29$. Для семян лобелии характерна неоднородность, связанная с различиями в степени их развития как в каждом из гнезд коробочки, так и коробочке в целом. В коробочке число нормально развитых семян (в морфологическом и физиологическом смысле) в среднем достигает $306 \pm 58$, недоразвитых $18 \pm 11$, а в каждом из гнезд коробочки $-147 \pm 35$ и $10 \pm 6$, соответственно.

Величина ФСП L. dortmanna в озерных экосистемах Тверской области доходит, в среднем, до $1621 \pm 451$ семя на один вегетативно-генеративный побег и зависит от числа коробочек на побеге. В популяции лобелии на оз. Бельское ФСП достигает $1726 \pm 527$ (для растений с 3-6 коробочками), в то время как на оз. Сиг - $1428 \pm 395$ (для растений с 3-5 коробочками).

В зависимости от глубины произрастания лобелии изменяется число генеративных побегов, а, следом, и число продуцируемых семян (табл. 1). Оптимальной для произрастания растений является глубина 50-70 см, на которой число продуцируемых семян достигает максимальных величин на исследуемую площадь (в нашем случае $-0,25 \mathrm{~m}^{2}$ ).

Таблица 1

Изменения числа продуцируемых семян Lobelia dortmanna на единицу площади с возрастанием глубины

\begin{tabular}{lccc}
\hline $\begin{array}{l}\text { Название } \\
\text { озера }\end{array}$ & $\begin{array}{c}\text { Глубина, } \\
\text { см }\end{array}$ & $\begin{array}{c}\text { Число генеративных } \\
\text { побегов, шт./0,25 м }\end{array}$ & $\begin{array}{c}\text { Число продуцируемых } \\
\text { семян, шт./0,25 м }\end{array}$ \\
\hline & 20 & $24,0 \pm 13,3$ & $41424 \pm 22956$ \\
Оз. Бельское & $50-60$ & $26,6 \pm 10,6$ & $45912 \pm 18296$ \\
& 70 & $57,5 \pm 0,5$ & $99245 \pm 863$ \\
& $90-100$ & $24,6 \pm 3,0$ & $42460 \pm 5178$ \\
Оз. Сиг & 60 & $9,7 \pm 5,2$ & $13858 \pm 7429$ \\
& $65-70$ & $13,3 \pm 3,0$ & $19002 \pm 4286$ \\
& $75-80$ & $5,6 \pm 1,5$ & $8001 \pm 2143$ \\
\hline
\end{tabular}

\section{Модульная структура}

В строении побегового тела L. dortmanna выделено 10 вариантов элементарных модулей (ЭМ; категории модулей по Savinykh (2007, 2008)):

1) укороченное междоузлие, узел с листом срединной формации и стеблеродными придаточными корнями либо без них;

2) укороченное междоузлие, узел с листом срединной формации, пазушной почкой и стеблеродными придаточными корнями либо без них;

3) укороченное междоузлие, узел с листом срединной формации, вегетативным побегом и стеблеродными придаточными корнями либо без них;

4) удлиненное междоузлие, узел с листом срединной формации;

5) удлиненное междоузлие, узел с листом срединной формации и пазушной почкой;

6) удлиненное междоузлие, узел с листом срединной формации и нереализованной боковой генеративной осью второго порядка (паракладием);

7) удлиненное междоузлие, узел с брактеей и нереализованной боковой генеративной осью второго порядка (паракладием);

8) удлиненное междоузлие, узел с брактеей и плодом;

9) удлиненное междоузлие, узел с брактеей и цветком;

10) удлиненное междоузлие, узел с брактеей и бутоном.

Полученные данные свидетельствуют об ограниченности и постоянстве числа ЭМ как в структуре розеточной (вегетативной), так и генеративной сфер растения.

Универсальный модуль (УМ) представлен монокарпическим дициклическим анизотропно нарастающим моноподиальным побегом, несущим терминальное соцветие (рис. 2).

В его строении выделяем следующие морфофункциональные зоны. Нижняя зона торможения (Н3Т) представлена базальной частью розеточного участка дициклического монокарпического побега. В пазухах листьев НЗТ боковые почки, как правило, отсутствуют. Основная функция НЗТ - ассимилирующая запас питательных веществ. Зона возобновления (3В) располагается в верхней трети розеточного участка побега. Здесь закладывается 1-2 пазушные почки, на базе которых формируются новые розеточные побеги. Верхняя зона торможения (ВЗТ) включает в себя 2-3 коротких метамера розеточного участка побега и до 1-2 длинных метамера с нормальными листьями, в пазухах которых пазушные структуры либо имеются, но в рост не трогаются, либо вообще отсутствуют. Скрытогенеративная зона (СГЗ) представлена 4-5 (6) длинными метамерами, в пазухах листьев (брактей) которых располагаются не реализующиеся в нормальных условиях боковые генеративные оси второго порядка (паракладии). СГЗ принимает участие при выносе соцветия над поверхностью воды, утрачивая при этом функцию семенной продуктивности. Главное соцветие (ГС) представлено открытой кистью, в составе которой можно единовременно наблюдать коробочки со зрелыми семенами, цветки и бутоны. Основная функция этой зоны - генеративная.

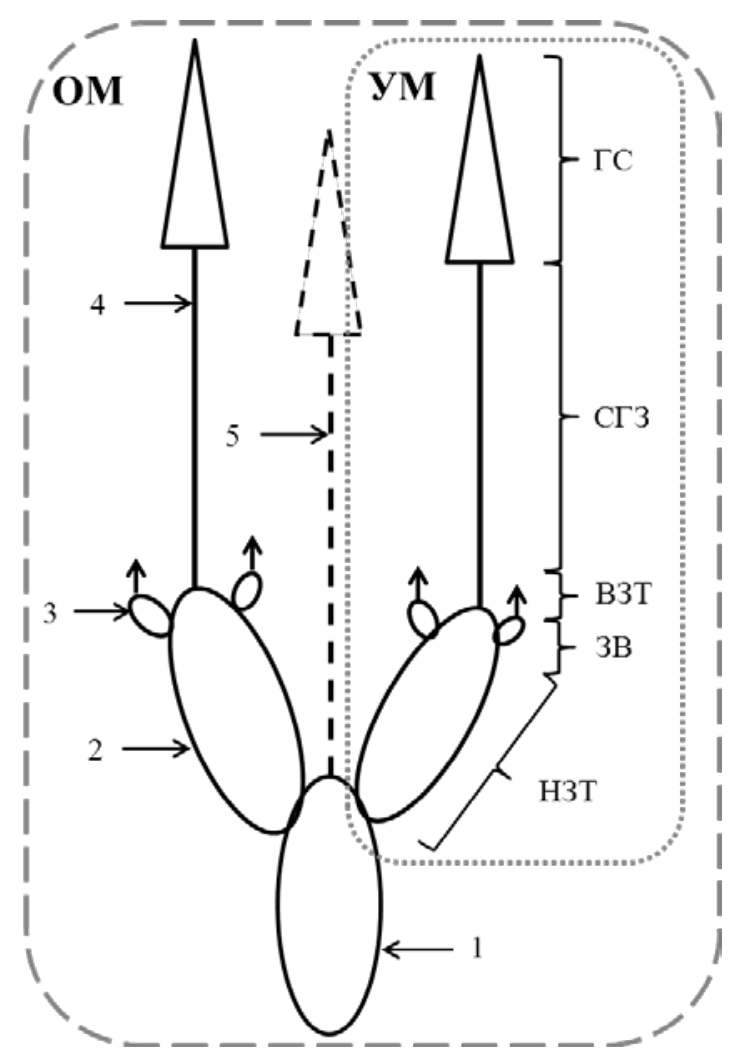

Рис. 2. Морфофункциональные зоны дициклического анизотропно и моноподиально нарастающего вегетативно-генеративного побега L. dortmanna: ОМ - основной модуль, УМ - универ-

сальный модуль, НЗТ - нижняя зона торможения, ЗВ - зона возобновления, ВЗТ - верхняя зона торможения, СГЗ - скрыто-

генеративная зона, ГС - главное соцветие; все структуры,

обозначенные цифрами 1-4, как на рис. 1, 5 - соцветие, отмершее в конце прошлого вегетационного сезона

Основной модуль (ОМ) L. dortmanna образован нарастающей симподиально системой побегов замещения, формирующейся на основе одного монокарпического полурозеточного побега. Модель побегообразования - симподиальная полурозеточная.

Одним из важных слагаемых, необходимых при решении вопросов использования естественного генофонда для интродукции, а также охраны популяций данного вида в природе, является изучение сезонного развития растения на конкретной территории. Ритм сезонного развития лобелии разбит на ряд последовательных этапов. 
Период относительного покоя протекает в течение осени зимы прошлого года до конца апреля нынешнего. Симподиальная побеговая система образована прошлогодним материнским розеточным участком побега (как правило, несущим листья), с отмершим терминальным цветоносом и одним - двумя молодыми боковыми вегетативными розеточными побегами. Основания розеточной части боковых побегов, как правило, погружены в грунт. Рост боковых побегов у L. dortmanna в течение зимнего периода продолжается, сопровождаясь при этом замедленным развертыванием молодых светло-зеленых листьев и образованием стеблеродных придаточных корней.

Вегетативная фаза. Начало вегетации L. dortmanna наблюдается на исследованных водоемах с конца апреля после полного таяния льда. В этот период начинается активное развитие верхушечных почек прошлогодних вегетативных дочерних розеточных побегов. При этом материнский прошлогодний монокарпический побег $n$-го порядка (с отмершим терминальным соцветием) еще несет на себе часть живых прошлогодних ассимилирующих листьев.

Фаза бутонизации. С начала мая у дочерних розеточных побегов L. dortmanna наблюдается закладка терминального соцветия. При этом уже в начале первой - второй декады мая, когда температура придонного слоя воды (глубина 30-50 см) возрастает с 7-9 до $19^{\circ} \mathrm{C}$, происходит закладка терминальных соцветий (практически у 50\% монокарпических побегов). Такое явление характерно для многих водных и прибрежноводных растений (Lebedeva and Lapirov, 2009). У отдельных дочерних розеточных побегов переход к фазе бутонизации мо- жет наблюдаться в июне - середине июля. При этом закладка генеративных органов в верхушечной почке и их дальнейшее развитие происходит без периода покоя, что можно характеризовать как вариант силлепсиса. В этот период листья на прошлогоднем участке материнского монокарпического побега $n$-го порядка обычно отмирают. У боковых побегов (с тронувшимися в рост терминальными цветоносами) в пазухах одного - двух последних листьев, расположенных в верхней части розеточного побега, отмечено наличие пазушных почек с $3 \pm 1$ листовыми зачатками. Они развиваются силлептически и обеспечивают дальнейшее ветвление побега до $n+2$ порядка. Если в течение вегетационного периода в терминальной почке вегетативного розеточного побега генеративные органы не закладываются, побег продолжает нарастать моноподиально и ортотропно.

Фаза иветения. Началу цветения лобелии предшествует быстрый рост метамеров соцветия в длину, вследствие чего генеративные части появляются над поверхностью воды. Появление цветоносов над поверхностью воды у лобелии наблюдается обычно к началу первой декады июня, когда температура воды достигает $20-21{ }^{\circ} \mathrm{C}$. Цветение продолжается в среднем около 40-47 суток. Вместе с цветением наблюдается активное развитие боковых побегов.

Фаза плодоношения. Созревание первых коробочек с семенами у лобелии наблюдается в конце первой декады июля. Начало фазы плодоношения совпадает с пиком цветения. К концу второй - третьей декады августа верхушки цветоносов засыхают, коробочки с семенами разрушаются. Морфологические особенности побегов в осенний период представлены в таблице 2 .

\section{Таблица 2}

Морфометрические характеристики материнского и дочерних розеточных побегов L. dortmanna

\begin{tabular}{|c|c|c|c|c|c|}
\hline \multirow{2}{*}{ Тип побега } & \multirow{2}{*}{$\begin{array}{c}\text { Число листьев } \\
\text { в розетке }\end{array}$} & \multirow{2}{*}{ Число корней } & \multicolumn{2}{|c|}{ Розеточная часть побега } & \multirow{2}{*}{$\begin{array}{c}\text { Емкость } \\
\text { верхушечной почки }\end{array}$} \\
\hline & & & длина & диаметр & \\
\hline \multicolumn{6}{|c|}{ конец второй декады августа } \\
\hline Материнский побег $n$-го порядка с отмирающим соцветием & $17,5 \pm 3,3$ & $95,0 \pm 8,0$ & $2,2 \pm 0,3$ & $0,6 \pm 0,1$ & - \\
\hline Дочерние боковые побеги $n$ + 1-го порядка & $3,0 \pm 1,0$ & единичны & $0,3 \pm 0,1$ & $0,2 \pm 0,0$ & $7,2 \pm 0,7$ \\
\hline \multicolumn{6}{|c|}{ первая декада сентября } \\
\hline $\begin{array}{l}\text { Материнский побег } n \text {-го порядка с отмирающим соцветием } \\
\text { Дочерние боковые побеги } n+1 \text {-го порядка }\end{array}$ & $\begin{array}{r}21,5 \pm 3,5 \\
6,3 \pm 1,7\end{array}$ & $\begin{array}{c}139,5 \pm 44,0 \\
11,7 \pm 2,9\end{array}$ & $\begin{array}{l}2,8 \pm 0,6 \\
0,5 \pm 0,2\end{array}$ & $\begin{array}{l}0,4 \pm 0,1 \\
0,3 \pm 0,1\end{array}$ & $\begin{array}{c}- \\
6,1 \pm 0,9\end{array}$ \\
\hline
\end{tabular}

Примечание: «-»-верхушечная почка отсутствует.

Окончание вегетащии. Темпы развития дочерних побегов замедляются при наступлении третьей декады августа, что приводит к снижению емкости их терминальных почек. Волновое воздействие приводит к обламыванию либо полеганию цветоносов и дальнейшему их отмиранию и разложению. Отмечаются процессы отмирания розеточного участка прошлогоднего вегетативно-генеративного побега. Последнее нередко сопровождается неспециализированой морфологической дезинтеграцией, приводящей к полному обособлению дочерних генеративных побегов. Этот процесс может наступать и в более ранние сроки.

Фаза вторичной деятельности. В течение осенне-зимнего периода побег продолжает выполнять функцию ассимиляции и запасания питательных веществ. Наряду с этим, хотя и в замедленном темпе, продолжается формирование стеблеродных придаточных корней и развертывание листьев дочерних боковых побегов.

Таким образом, по характеру ритма сезонного развития (Borisova, 1965) L. dortmanna можно отнести к группе длительновегетирующих летнезимнезеленых растений со средне- и позднелетним периодом цветения.

\section{Обсуждение}

Жизненную форму лобелии Дортманна в «Биологической флоре Британских островов» Woodhead (1951, p. 485) описывает достаточно просто: «розеткообразующий многолетник, обычно погруженный в вегетативном состоянии». Ранее Glück (1924) выделял две «формы»: f. ramosa Murbeck - большое погруженное пышное растение с ветвящимся стеблем и $\mathrm{f}$. terrestris Glück - наземное, сильно редуцированное и маленькое растение. Редкая форма paniculata Prahl - с соцветием, ветвящимся в его нижней части, отмечена немецким ученым Hegi (по: Woodhead, 1951). Несмотря на это, Pedersen and Sand-Jensen (1992) показали, что погруженная и наземная формы сохраняют одинаковый тип морфологии, скорости роста и физиологии. В настоящей работе рассматривается погруженная (наиболее распространенная) форма лобелии.

Philippov et al. (2016, p. 86) характеризуют основную жизненную форму L. dortmanna как «внутриводно-столонное кистекорневое многолетнее поликарпическое травянистое растение с чередованием двух фенобиоморф: длительной вегетативно неподвижной моноцентрической кистекорневой и кратковременной вегетативно подвижной явнополицентрической внутриводно-столонной». Отметим, что на многочисленном тщательно просмотренном живом и гербарном материале нами не обнаружено наличие ««шагающих» удлиненных вегетативных моноциклических эфемерных побегов, нарастающих в толще воды (внутриводных столонов)» (Philippov et al., 2016, p. 86).

На основании собственных материалов по морфологии и модульной структуре, с использованием алгоритма, применяемого в современных биоморфологических исследованиях (Savinykh and Cheryomushkina, 2015), мы характеризуем жизненную форму L. dortmanna как травянистый поликарпик, неявнополицентрический короткокорневищный малолетник вегетативного происхождения с кистекорневой системой и ранней неспециализированной морфологической дезинтеграцией. 
У зеленых ассимилирующих листьев лобелии, как отмечают Pedersen and Sand-Jensen (1992), практически отсутствуют устьица (кроме незначительного количества на адаксиальной стороне, близкой к основанию листа), в отличие от брактей, имеющих многочисленные устьица. Несмотря на это, брактеи играют незначительную роль в короткой части жизненного цикла (Pedersen and Sand-Jensen, 1992). Наши наблюдения не подтверждают точку зрения Moeller (1978), что в течение осени и зимы лобелия Дортманна не продуцирует новые листья. В этой связи справедливо мнение Hutchinson (1975), который считает, что образование и развитие листьев в зимний период идет медленнее, чем в другие сезоны. Исследователь объясняет это тем, что существование многих водных растений в умеренном климатическом поясе затруднено из-за чрезмерно низких зимних температур и уменьшения интенсивности света из-за льда и снежного покрова. Таким образом, наличие зимнезелености у L. dortmanna является, по-видимому, следствием реализации наследственно обусловленных ритмов жизнедеятельности, сохранившихся «как реликтовый признак принадлежности предковых видов к флорам сезонных климатов прошлого» (Mihalin et al., 2010, p. 119).

Как показано нами, формирование побегов $n+1$ порядка ветвления (боковые розеточные побеги) происходит в конце периода закладки терминального соцветия или на начальных этапах его развития. Например, на оз. Бельское в начале второй декады мая 2016 года обнаружены растения, имеющие зачаточное соцветие (длиной $0,5-0,9$ см) и несущие $1-3$ боковые почки (длиной до 0,9 мм с 2-4 листовыми зачатками) в пазухах верхних ассимилирующих листьев. В дальнейшем из этих почек формируются боковые побеги, представляющие собой вегетативные диаспоры. Аналогичные структуры описаны у лобелии Szmeja (1987). Однако их развитие, по его мнению, происходит в постгенеративную фазу и сопровождается увяданием цветоноса и всех листьев. По-видимому, сроки формирования боковых побегов напрямую зависят от географических различий в расположении озер.

Обнаруженные у лобелии с Тверских озер специфические утолщения корней (чаще в апикальной части, реже по всей поверхности) связаны с наличием везикулярно-арбускулярной микоризы (vesicular-arbuscular - VA), впервые описанной в конце 1970-х годов у изоэтидов в датских олиготрофных озеpax (Søndergaard and Laegaard, 1977). По материалам, полученным из южных озер Швеции, суммарная длина корней лобелии, колонизированная грибами, колеблется от $34 \%$ до $85 \%$, при этом арбускулярная колонизация - 28-83\%, везикулярная 6-65\% (Nielsen et al., 2004). Подобный симбиоз чрезвычайно важен для изоэтидов, и, в частности, для лобелии, поскольку позволяет ей существовать при низком трофическом уровне озерных седиментов.

Рассматривая генеративную сферу растения, заметим, что формирование побегов из вегетативных почек в нижней части соцветия (в пазухе первого - второго листа срединной формации) мы не наблюдали, хотя, это, по-видимому, возможно. Так, Makavičiūtė and Sinkevičienė (2011) у лобелии Дортманна (озеро Салинис, Литва) обнаружили молодое вегетативное растение в нижней части соцветия (на расстоянии 25 мм от основания цветоносной оси). Подобное явление, по мнению этих авторов, связано со специфическими условиями окружающей среды (затенение и погружение растений в осадочные слои, а также природное и антропогенное эвтрофирование).

В отличие от семян лобелии из Шотландских озер, большинство из которых оказалось нежизнеспособными (Farmer and Spence, 1987), в популяциях, изученных нами, число подобных составляло около $10 \%$. Сравнивая популяции лобелии в озерных экосистемах Тверской области и в Белорусских озеpax (озеро Бредно (Marozau, 2013)), отметим, что число зрелых полноценных семян в плоде у первых значительно выше, чем у вторых (306,4 $\pm 57,6$ и 155,4 $\pm 4,9$, соответственно).

Как и в случае с калипсо и дремликом (Chuprakova and
Savinykh, 2012), у лобелии Дортманна функциональная роль основных зон побегового комплекса обеспечивается минимальным числом (от 1 до 3) вариантов ЭМ. При этом самой простой структурой обладают НЗТ, ЗВ и ВЗТ, включающие в себя не более одного - двух вариантов ЭМ. Отсутствие спящих почек в пазухах листьев является главным фактором, исключающим как структурную, так и онтогенетическую поливариантность развития этого растения. Последнее обусловлено жесткой адаптацией растения к условиям внешней среды, что говорит о его уязвимости.

В целом, ритм сезонного развития лобелии в Тверских озерах сходен с таковым в одном из олиготрофных озер Польши (Szmeja, 1987). Однако в исследованных нами популяциях наблюдается сдвиг ряда фенологических фаз растений на более ранние сроки. Например, закладка цветоносов у лобелии в озерах Тверской области происходит в начале мая, а в польских популяциях этого растения - в конце мая. При этом пик цветения и фаза плодоношения наступают в близкие сроки. Это подтверждает ранее высказанную точку зрения (Voroshilov, 1960) о том, что в отношении признака ритма развития между близкими (одинаковыми) видами наблюдаются как черты сходства, так и черты различия.

\section{Выводы}

Согласно результатам исследования, по жизненной форме L. dortmanna - травянистый поликарпик, неявнополицентрический короткокорневищный малолетник вегетативного происхождения с кистекорневой системой и ранней неспециализированной морфологической дезинтеграцией. Нарастающая симподиально побеговая система растения представлена двумя типами разновозрастных анизотропных побегов замещения: дициклическими вегетативно-генеративными полурозеточными и однолетними вегетативными розеточными.

Наличие специфических утолщений, как в средней, так и в апикальной частях корней лобелии Дортманна, связано с формированием здесь везикулярно-арбускулярной микоризы, позволяющей растению существовать в водоемах с низким трофическим уровнем. Величина ФСП $L$. dortmanna в озерных экосистемах Тверской области в среднем достигает $1621 \pm 451$ семян на один вегетативно-генеративный побег. Оптимальной глубиной для произрастания этого растения является 50-70 см; на этой глубине число генеративных побегов, а, соответственно, и число продуцируемых семян на площади 0,25 м $^{2}$ достигает максимальных величин. Модульная структура лобелии представлена 10 вариантами ЭМ. ОМ формируется на основе монокарпического дициклического анизотропного моноподиального побега, несущего терминальное соцветие. Функциональная роль основных зон монокарпического побега обеспечивается минимальным числом вариантов ЭМ. По характеру ритма сезонного развития L. dortmanna относится к группе длительновегетирующих летнезимнезеленых растений со средне- и позднелетним периодом цветения.

Полевые работы выполнены при частичной финансовой поддержке Программы фундаментальных исследований Президиума РАН «Живая природа: современное состояние и проблемы развития», подпрограмма «Биоразнообразие: состояние и динамика».

\section{References}

Armand, M. L. (1912). Recherches morphologiques sur le Lobelia dortmanna L. Revue Generale de Botanique, 24(288), 465-478.

Borisova, I. V. (1965). Ritmy sezonnogo razvitiya stepnyh rasteniy i zonalnyh tipov stepnoy rastitelnosti Centralnogo Kazahstana [Seasonal development rhythms of steppe plants and zonal types of steppe vegetation of Central Kasakhstan]. Acta Instituti Botanici Nomine V. L. Komarovii Academiae Scientiarum URSS. Series III (Geobotanica), 17, 64-99.

Chuprakova, E. I., \& Savinykh, N. P. (2012). Struktura osobey Calypso bulbosa (L.) Oakes i Epipactis palustris (L.) Crantz s pozicii modulnoy 
organizacii [Structure of individuals of Calypso bulbosa (L.) Oakes and Epipactis palustris (L.) Crantz from position of modular organization]. Yaroslavl Pedagogical Bulieten, 3(4), 97-102 (in Russian).

Farmer, A. M., \& Spence, D. H. N. (1987). Flowering, germination and zonation of the submerged aquatic plant Lobelia dortmanna L. Journal of Ecology, 75(4), 1065-1076.

Glück, H. (1924). Biologische und morphologische Untersuchungen über Wasser- und Sumpfgewächse. IV. Untergetauchte und Schwimmblattflora. Verlag von Gustav Fischer, Jena (in Germany).

Gubanov, I. A., Kiselyova, K. V., Novikov, V. S., Tihomirov, V. N. (2004). Illyustrirovannyy opredelitel rasteniy Sredney Rossii. Tom 3. Pokrytosemennye (Dvudol'nye: Razdel'nolepestnye) [Illustrated key to plants of Central Russia. Vol. 3. Angiosperms (Bipartite: Polypetalae)]. KMK, Moscow (in Russian).

Hutchinson, G. E. (1975). A treatise on limnology. Vol. 3. Limnological botany. Wiley and Sons, New York.

Lamentowicz, M., \& Milecka, K. (2004). Lobelia dortmanna L. seeds in lake sediments from the Tuchola Forest (Pomerania, Northern Poland). Acta Palaeobotanica, 44(2), 281-285.

Lebedeva, O. A., \& Belyakov, E. A. (2016). Osobennosti prorastaniya semyan Lobelia dortmanna (Lobeliaceae) v usloviyah ehksperimenta [Features of seed germination of Lobelia dortmanna (Lobeliaceae) under experimental conditions]. Rastitelnye Resursy, 52(3), 375-380 (in Russian).

Lebedeva, O. A., \& Lapirov, A. G. (2009). The rhythm of the seasonal development and morphological polyvariation Batrachium circinatum (Sibth.) Spach at the Rybinsk reservoir. Inland Water Biology, 2(3), 223-227.

Makavičiūtè, J., \& Sinkevičienè, Z. (2011). Unusual vegetative propagation of water Lobelia (Lobelia dortmanna) in Lake Salinis (Lithuania). Botanica Lithuanica, 17(4), 185-187.

Markov, M. V. (2017). K izucheniyu polushnikovyh oligotrofnyh ozer Tverskoy oblasti: Fotosinteziruyushchaya biota kak indikator ih troficheskogo statusa [Research on the Isoetid oligotrophic Lakes in Tver region: Photosynthetic biota as their trophic state indicator]. Russian Journal of Ecosystem Ecology, 2(1), 1-19 (in Russian).

Marozau, I. M. (2013). Sravnitelnoe izuchenie i ehkologo-biologicheskie osobennosti Lobelii dortmanna pri reintrodukcii [The comparative and ecological-biological features of Lobelia dortmanna with reintroduction]. Proceedings of the Nacional Academy of Sciences of Belarus. Biological Series, 4, 30-34 (in Belarus).

Mihalin, M. V., Popkov, B. V., \& Priluckiy, A. N. (2010). Sezonnyy ritm rasteniy i perspektivy ego transformacii [Seasonal rhythm of plants and prospects for its transformation]. Byulleten Botanicheskogo Sada Instituta DVO RAN, 5, 117-132 (in Russian).

Moeller, R. E. (1978). Seasonal changes in biomass, tissue chemistry and net production of the evergreen hydrophyte Lobelia dortmanna. Canadian Journal of Botany, 56(12), 1425-1433.

Møller, C. L., \& Sand-Jensen, K. (2011). High sensitivity of Lobelia dortmanna to sediment oxygen depletion following organic enrichment. New Phytologist, 190(2), 320-331.
Nevskiy, M. L. (1956). O nekotorom svoeobrazii flory i rastitel'nosti Vyshnevolockogo rayona Kalininskoy oblasti [About some peculiarityes of flora and vegetation of Vyshnevolotsky district of the Kalinin region]. Uchenye Zapiski Kalininskogo Gosudarstvennogo Pedagogicheskogo Instituta imeni M. I. Kalinina, 20, 5-46 (in Russian).

Nielsen, K. B., Kjøller, R., Olsson, P. A., Schweiger, P. F., Andersen, F. Ø., \& Rosendahl, S. (2004). Colonisation and molecular diversity of arbuscular mycorrhizal fungi in the aquatic plants Littorella uniflora and Lobelia dortmanna in southern Sweden. Mycological Research, 108(6), 616-625.

Pedersen, O. \& Sand-Jensen, K. (1992). Adaptations of submerged Lobelia dortmanna to aerial life form: Morphology, carbon sources and oxygen dynamics. Oikos, 65(1), 89-96.

Philippov, D. A., Bobroff, Y. A., Czhobadze, A. B., \& Levashov, A. N. (2016). Lobelia dortmanna (Lobeliaceae) v Vologodskoy oblasti [Lobelia dortmanna (Lobeliaceae) in the Vologda region]. Vestnik Sankt-Peterburgskogo Universiteta. Seriya 3. Biologiya, 1, 84-99.

Philipson, W. R. (1948). Studies in the development of the inflorescence: V. The raceme of Lobelia dortmanna L., and other Campanulaceous inflorescences. Annals of Botany, 12(46), 147-156.

Pulido, C., Keijsers, D. J. H., Lucassen, E. C. H. E. T., Pedersen, O., \& Roelofs, J. G. M. (2012). Elevated alkalinity and sulfate adversely affect the aquatic macrophyte Lobelia dortmanna. Aquatic Ecology, 46(3), 283-295.

Sand-Jensen, K., Borum, J., \& Binzer, T. (2005). Oxygen stress and reduced growth of Lobelia dortmanna in sandy lake sediments subject to organic enrichment. Freshwater Biology, 50(6), 1034-1048.

Savinykh, N. P. (2007). Modul'naya organizaciya rasteniy [Modular organization of plants]. In: Ontogeneticheskiy atlas rasteniy [Ontogenetic atlas of plants]. Izdatelstvo Mariyskogo Gosudarstvennogo Universiteta, Yoshkar-Ola, 1534 (in Russian).

Savinykh, N. P. (2008). Primenenie koncepcii modul'noy organizacii k opisaniyu struktury rasteniya [Application of modular concept to description of plant structure]. In: Sovremennye podhody k opisaniyu struktury rasteniy [Contemporary approach to description of plant structure]. LLC "Loban", Kirov, 47-69 (in Russian).

Savinykh, N. P., \& Cheryomushkina, V. A. (2015). Biomorphology: Current status and prospects. Contemporary Problems of Ecology, 8(5), 541-549.

Søndergaard, M., \& Laegaard, S. (1977). Vesicular - arbuscular mycorrhiza in some aquatic vascular plants. Nature, 268, 232-233.

Szmeja, J. (1987). The seasonal development of Lobelia dortmanna L. and annual balance of its population size in an oligotrophic lake. Aquatic Botany, 28(1), 15-24.

Vaynagiy, I. V. (1974). O metodike izucheniya semennoy produktivnosti rasteniy [Concerning the methodology for the studying of plants' seed productivity]. Botanicheskiy Zhurnal, 59(6), 826-831 (in Russian).

Voroshilov, V. N. (1960). Ritm razvitiya u rasteniy [The rhythm of plants development]. Izdatelstvo Akademii Nauk SSSR, Moscow (in Russian).

Woodhead, N. (1951). Biological flora of the British Isles: Lobelia dortmanna L. Journal of Ecology, 39(2), 458-464. 